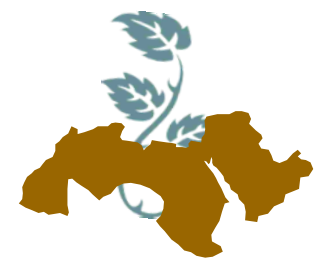

\title{
EFFECT OF ZEOLITE, POTASSIUM HUMATE, BIOCHER AND BIOFERTILIZER ON AMMONIA LOSS FROM CALCAREOUS SOIL
}

\author{
Shimaa, Y. Oraby; M. Elbordiny; E.M. Khaled and M. El-Neenah \\ Soil Science Department, Faculty of Agriculture, Ain Shams University, Cairo, Egypt
}

Keywords: Ammonia loss, Zeolite, Biofertilizer, Urea, Calcareous Soil, Air pollution.

\begin{abstract}
Application of urea to agricultural soil may pollute the air environment due to ammonia $\left(\mathrm{NH}_{3}\right)$ volatilization. Zeolite, Humate, biocher and biofertilizer may be used to control $\mathrm{N}$ losses resulting from urea transformation to $\mathrm{NH}_{3}$. A laboratory soil incubation experiment was conducted to determine the effects of zeolite, K-humate, biocher and biofertilizer on controlling $\mathrm{NH}_{3}$ losses out of applied urea. Calcareous soil sample from El-Nobaria area, Beheira Governorate was treated with different amendments and incubated under laboratory condition for 13 weeks. Results obtained showed that soil treated with urea in the presence of different amendments significantly reduced $\mathrm{NH}_{3}$ release from urea as compared to the control. During the first 80 days of the incubation ammonia losses were highest in control compared to soil treated with the different amendments. Biocher treatment showed the highest effect in reducing ammonia volatilization from calcareous soil. Therefore, treating calcareous soil with biocher and biofertilizer can decrease were losses as ammonia and increase nitrogen availability in soil, and hence reduces air pollution by ammonia.
\end{abstract}

\section{INTRODUCTION}

Because of its high $\mathrm{N}$ content and low price urea is considered the most widely used Nitrogen fertilizer in agriculture. Depending on soil $\mathrm{pH}$, moisture content, soil temperature and application method, urea undergoes chemical transformation to produce either $\mathrm{NH}_{4}{ }^{+}$or $\mathrm{NO}_{3}{ }^{-}$(He, et al 2002). Miles, et al (2011) reported that maximum $\mathrm{NH}_{3}$ emission was up to 7 times greater at $40.6^{\circ} \mathrm{C}$ vs.at $18.3^{\circ} \mathrm{C}$. In addition, $\mathrm{NH}_{3}$ loss is known to the low at $\mathrm{pH}$ below 7 . Because $\mathrm{NH}_{4}{ }^{+}$is positively charged, it can be held by the negative sites of soils (e.g., clay and humus); therefore, $\mathrm{NH}_{4}{ }^{+}$leaches was less in mineral soils which are particularly high in clay (Brady and Weil, 2010). In contrast, $\mathrm{NH}_{4}^{+}$leaching is significant in coarse-textured sands and some muck soils (Vitosh, et al 1995). Thus, agricultural research can leading to management practices that improve $\mathrm{N}$ utilization efficiency and decrease $\mathrm{N}$ losses (Powlson et al 2008). Reducing loss of mineral $\mathrm{N}$ from agricultural systems is difficult to achieve through reduction of $\mathrm{N}$ fertilizers use (Wolf and Snyder, 2003).

Clinoptilolite zeolite is a mineral with a unique structure which allows entrapping or releasing various cations due to its high cation exchange capacity (Kamarudin, et al 2003). Therefore, zeolite can be used to control $\mathrm{N}$ loss from urea because of the small molecular size of the open-ringed structure of clinoptilolite zeolite which physically protect $\mathrm{NH}_{4}{ }^{+}$ ions against microbial nitrification (Fergunson and Pepper, 1987). Studies have shown that the use of clinoptilolite zeolite and $\mathrm{N}$ fertilizers improves $\mathrm{N}$ use efficiency (Bouzo, et al 1994 and Ahmed, et al 2009). The increased efficiency of $N$ utilization when urea is used together with clinoptilolite zeolite has been demonstrated by a number of researchers (Rabai, et al 2013). In contrast, unbalanced use of $\mathrm{N}$ fertilizers could cause environmental pollution (McGilloway, et al 2003). 
To manage the risk of $\mathrm{NH}_{3}$ loss, several studies have been done to alleviate the problem. Research has shown that one of the ways to enhance plant $\mathrm{N}$ use efficiency of urea is to mix with humic acids (Rivera-Cruz, et al 2008). Humic acids are known to have chemical properties such as high total CEC useful in retaining $\mathrm{NH}_{4}{ }^{+}$(Sharma and Kumar, 2008). Humic substances are the most chemically active compounds in soils with cation and anion exchange capacities far exceeding those of clays and having various capabilities beneficial to agricultural soils (Aulakh and Malhi 2005). The major sources of humic substances, in generally, can be found in coal as it contains the largest amount of humified substances particularly, humic acid (HA), fulvic acid (FA) and humin. Paramasivam, et al (2001) reported that commercial grade lignite from North Dakota compose substantial amount of HA $(99.0 \%)$ in contrast to that of FA $(1 \%)$. Lignite or leonardite samples were also noted, to compose $99.5 \% \mathrm{HA}$ and $0.5 \%$ of FA (Wolf and Snyder 2003).

Biochar is persistent in soils and its beneficial effects are longer lasting when compared to other forms of organic matter such as manure. Biochar application can increased soil organic carbon levels (McHenry, 2011) and can improve soil structure (Glaser, et al 2002). Its application can be improve the soil's ability to retain moisture (Steiner, et al 2010), can prevent nutrient leaching (Spokas, et al 2012) and also increases cation exchange capacity (Clough and Condron, 2010). IN addition to biochar improves the biological conditions of soils, increase soil microbial biomass and support beneficial organisms like earthworms (Lehmann, et al 2011).

Biological fertilization is based on the use of natural inputs including fertilizers, decaying of the remains of organic matter, excess crops, domestic sewage, animal manure and microorganisms such as fungi and bacteria (Chirinos, et al 2006). Biofertilization application very important in providing the plants with their nutritional requirements without having an undesirable impact on the environment (Abou El-Yazied and Sellim, 2007). Moreover, biofertilizers are known to improve fixation of nutrients in the rhizosphere, produce growth stimulants for plants, improve soil stability and provide biological control (Rivera-Cruz, et al 2008). In addition, biofertilizers containing azotobacter can produce many growth regulators such as IAA and GA2 which are positively influence plant growth (Sharma and Kumar, 2008). Hence, this study aimed to investigate the effect of zeolite, K-Humic, biocher and biofertilizer in reducing ammonia volatilization from urea fertilizer applied to calcareous soil. Moreover, to evaluate the effectiveness of biochar as a soil conditioner and fertility enhancer and ascertain its nutrient-supplying capability when applied singly or in combination with biofertilizer. Comparison between the effect of different rates of biochar application on soil health and crop productivity in the sandy soil was also examined.

\section{MATERIALS AND METHODS}

In this study, calcareous soil samples were collected from El-Nobaria area, Beheira Governorate, Egypt, (30 $2815.85 \mathrm{~N}$ latitude and 3047 7.23" E longitude). Some physical and chemical characteristic of the studied soil samples were determined according to Jackson (1958) and are shown in Table (1).

Zeolite was taken from the El-Ahram Mining Company. There after dried in an oven at $100 \pm$ $5 \circ \mathrm{C}$ for $24 \mathrm{~h}$. The chemical analyses and some characteristics of zeolite are presented in Tables (2 and 3). Potassium humate powder made in China, as well as biocher from bring wood were used in this experiment. Some properties of the biochar and potassium humate are shown in Tables (3 and 4).

Biofertilizer solution was prepared by mixing a combination of natural substances present in the environment such as straw, plant leaves, rice haske beside soil from rhizosphere, and was prepared as followes:

One $\mathrm{Kg}$ soil was collected from rhizospher at a depth of $5 \mathrm{~cm}$ and mixed with $2 \mathrm{Kg}$ of the rice haske and $1 \mathrm{Kg}$ of green leaves. All were mixed in a dish, with a hole in the middle, then the dish was covered, and placed place in a dark for 30 days. After that the mixture was placed in a bag and potted in tank containing 75 liters of water and 15 liters of molass, with stirring for 30 days. Then, the clear solution was analyzed and used as biofertilizer. The chemical composition of the obtained biofertilizer is presented in Table (4). The biological analysis of biofertilizer is shown in Table 5 . 
Table 1. Some physical and chemical characteristics of the calcareous soil sample

\begin{tabular}{|c|c|}
\hline Characteristics & \\
\hline Particle size distribution (\%) & \\
\hline Sand & 96.2 \\
\hline Silt & 2.70 \\
\hline Clay & 1.10 \\
\hline Texture Class & Sandy \\
\hline $\mathrm{Sp}(\%)$ & 22.5 \\
\hline CEC (Cmolc. kg $\left.{ }^{-1}\right)$ & 8.40 \\
\hline $\mathrm{EC}_{\mathrm{e}}\left(\mathrm{dS} \cdot \mathrm{m}^{-1}\right)$ & 0.71 \\
\hline $\mathrm{pH}(1: 2.5)$ & 8.26 \\
\hline $\mathrm{OM}(\%)$ & 0.47 \\
\hline $\mathrm{CaCO}_{3}(\%)$ & 18.5 \\
\hline SAR & 0.655 \\
\hline Soluble ions $\left(\mathrm{Cmol}^{\mathrm{kg}}{ }^{-1}\right)$ & \\
\hline $\mathrm{Ca}^{2+}$ & 3.53 \\
\hline $\mathrm{Mg}^{2+}$ & 2.11 \\
\hline $\mathrm{Na}^{+}$ & 1.10 \\
\hline $\mathrm{K}^{+}$ & 0.36 \\
\hline $\mathrm{Cl}^{-}$ & 3.19 \\
\hline $\mathrm{HCO}_{3}^{-}$ & 2.35 \\
\hline $\mathrm{CO}_{3}^{-2}$ & - \\
\hline $\mathrm{SO}_{4}^{-2}$ & 1.56 \\
\hline $\begin{array}{c}\text { Chemically available nutrients } \\
\qquad\left(\mathrm{mg} \cdot \mathrm{kg}^{-1}\right)\end{array}$ & \\
\hline $\mathrm{N}$ & 14.0 \\
\hline$P$ & 2.54 \\
\hline $\mathrm{K}$ & 94.0 \\
\hline Total content of nutrients ( \%) & \\
\hline $\mathrm{N}$ & 0.388 \\
\hline $\mathrm{P}$ & 0.003 \\
\hline $\mathrm{K}$ & 0.014 \\
\hline
\end{tabular}

Table 2. Chemical composition of zeolite

\begin{tabular}{|c|c|}
\hline & $\%$ \\
\hline $\mathrm{SiO}_{2}$ & 71.0 \\
$\mathrm{Al}_{2} \mathrm{O}_{3}$ & 11.8 \\
$\mathrm{Fe}_{2} \mathrm{O}_{3}$ & 0.64 \\
$\mathrm{CaO}$ & 1.35 \\
$\mathrm{MgO}$ & 1.40 \\
$\mathrm{SO}_{3}$ & 1.74 \\
$\mathrm{~K}_{2} \mathrm{O}$ & 0.69 \\
$\mathrm{Na}_{2} \mathrm{O}$ & 0.27 \\
$\mathrm{CaCO}_{3}$ & 1.74 \\
$\mathrm{P}_{2} \mathrm{O}_{5}$ & 0.02 \\
\hline
\end{tabular}

Table 3. Some characteristics of zeolite and biocher

\begin{tabular}{|c|c|c|}
\hline Characteristics & Zeolite & Biocher \\
\hline $\mathrm{pH}(1: 2.5)$ & 7.58 & 9 \\
\hline $\mathrm{ECe}\left(\mathrm{dS} . \mathrm{m}^{-1}(1: 2.5)\right)$ & 0.88 & 4.75 \\
\hline CEC (Cmolc. $\left.\mathrm{kg}^{-1}\right)$ & 77.85 & 18.9 \\
\hline \multicolumn{3}{|c|}{ Total elements content (\%) } \\
\hline $\mathrm{Ca}$ & 4.00 & - \\
\hline $\mathrm{Mg}$ & - & - \\
\hline $\mathrm{N}$ & 0.31 & 1.25 \\
\hline$P$ & 0.29 & 0.55 \\
\hline $\mathrm{K}$ & 0.86 & 1.13 \\
\hline $\mathrm{Na}$ & 0.34 & - \\
\hline \multicolumn{3}{|c|}{ Chemically available nutrients ( $\mathrm{mg} \cdot \mathrm{kg}^{-1}$ ) } \\
\hline $\mathrm{N}$ & 66.15 & 84 \\
\hline$P$ & 2.33 & 6.54 \\
\hline K & 302 & - \\
\hline \multicolumn{3}{|c|}{ Soluble cations and anions (meq. $\mathrm{I}^{-1}$ ) } \\
\hline $\mathrm{Ca}^{2+}$ & 5.00 & 2.8 \\
\hline $\mathrm{Mg}^{2+}$ & 0.00 & 1.8 \\
\hline $\mathrm{Na}^{+}$ & 2.00 & 13.5 \\
\hline $\mathrm{K}^{+}$ & 2.16 & 22.8 \\
\hline $\mathrm{Cl}^{-}$ & 1.60 & 46 \\
\hline $\mathrm{HCO}_{3}^{-}$ & 2.00 & 1.6 \\
\hline $\mathrm{CO}_{3}^{-2}$ & - & - \\
\hline $\mathrm{SO}_{4}^{-2}$ & 5.56 & - \\
\hline
\end{tabular}


Table 4. Some characteristics of potassium humate and biofertilizer

\begin{tabular}{|c|c|c|}
\hline Characteristics & $\begin{array}{l}\text { Potassium } \\
\text { humate }\end{array}$ & Biofertilizer \\
\hline $\mathrm{pH}$ & 9.17 & 5.83 \\
\hline $\mathrm{ECe}\left(\mathrm{dS} \cdot \mathrm{m}^{-1}(1: 10)\right)$ & 5.32 & 4.51 \\
\hline bulk density $\left(\mathrm{g} \cdot \mathrm{cm}^{-3}\right)$ & $\mathrm{ND}^{*}$ & ND \\
\hline \multicolumn{3}{|c|}{ Chemically available nutrients $\left(\mathrm{mg} . \mathrm{I}^{-1}\right)$} \\
\hline $\mathrm{N}$ & 130.6 & 896.0 \\
\hline$P$ & 13.13 & 2.848 \\
\hline $\mathrm{K}$ & 1947 & 4988 \\
\hline \multicolumn{3}{|l|}{ Chemical constituent } \\
\hline $\begin{array}{l}\text { Total free amino } \\
\text { acids (FAA). }\end{array}$ & $N^{*}$ & 2.123 \\
\hline VEL & ND & 0.790 \\
\hline LYS & ND & 1.142 \\
\hline Proline & ND & 0.089 \\
\hline Total Phenol. & ND & 0.345 \\
\hline Total S. Sugar & ND & 0.495 \\
\hline $\begin{array}{c}\text { Antioxidant Capaci- } \\
\text { ty, }(1: 5000)\end{array}$ & ND & 45.00 \\
\hline Total Protein & ND & 25.00 \\
\hline \multicolumn{3}{|c|}{ Total elements content (\%) } \\
\hline $\mathrm{N}$ & 1.615 & 19.00 \\
\hline $\mathrm{P}$ & 1.082 & 3.530 \\
\hline $\mathrm{K}$ & 0.526 & 2.594 \\
\hline \multicolumn{3}{|c|}{ Humic and Fulvic Compounds (\%) } \\
\hline Humic acid & 61.70 & 9.00 \\
\hline Fulvic acid & 38.33 & 91.0 \\
\hline
\end{tabular}

$N^{*}=$ Not Detected
Table 5. Biological analyses of biofertilizer

\begin{tabular}{|c|c|c|}
\hline \multicolumn{3}{|c|}{ Parameters } \\
\hline $\begin{array}{c}\text { Total count } \\
\text { Bacteria }\end{array}$ & $\begin{array}{l}\text { CFU/ml } \\
10^{6} \times 176\end{array}$ & $\begin{array}{c}\text { Bacillus sp. } \\
\text { Micrococcus sp. } \\
\text { Streptomyces } \\
\text { sp. } \\
\text { Short rods }\end{array}$ \\
\hline $\begin{array}{l}\text { Total count } \\
\text { mold \& yeast }\end{array}$ & $\begin{array}{l}36 \times 10^{4} \\
\mathrm{CFU} / \mathrm{ml}\end{array}$ & $\begin{array}{c}\text { Yeast } \\
\frac{\text { Aspergillus sp. }}{\text { Rhizopus sp. }} \\
\frac{\text { Penicillium sp. }}{}\end{array}$ \\
\hline $\begin{array}{c}\text { Total Coliform } \\
\text { groub }\end{array}$ & \multicolumn{2}{|c|}{$\mathrm{CFU} / \mathrm{ml} 0.0$} \\
\hline $\begin{array}{c}\text { Total Fecal } \\
\text { E. Coli }\end{array}$ & \multicolumn{2}{|c|}{$0.0 \mathrm{CFU} / \mathrm{ml}$} \\
\hline $\begin{array}{l}\text { Detection of } \\
\text { Salmonella sp. }\end{array}$ & \multicolumn{2}{|r|}{-} \\
\hline $\begin{array}{l}\text { Detection of } \\
\text { Shigella sp. }\end{array}$ & \multicolumn{2}{|r|}{-} \\
\hline $\begin{array}{c}\text { Detection of } \\
\text { B. cerus }\end{array}$ & \multicolumn{2}{|r|}{-} \\
\hline $\begin{array}{c}\text { Detection of } \\
\text { Listeria sp. }\end{array}$ & \multicolumn{2}{|r|}{-} \\
\hline Protein analysis & \multicolumn{2}{|r|}{+} \\
\hline $\begin{array}{l}\text { Cellulose } \\
\text { analysis }\end{array}$ & \multicolumn{2}{|r|}{+} \\
\hline Starch analysis & \multicolumn{2}{|r|}{+} \\
\hline Fat analysis & \multicolumn{2}{|r|}{+} \\
\hline Antibiotics & \multicolumn{2}{|r|}{+} \\
\hline
\end{tabular}


The following treatments were conducted in order to study the effect of different sources of amendments (zeolite, potassium humate, biochar and biofertilizer) mixed with calcareous soil at different incubation periods on the loss of ammonia, the management of the total treatments with three replicates were as follow:

1- Control (Soil without any amendments).

2- Zeolite (1\%).

3- Potassium humate (1\%)

4- Biocher (1\%)

5- Biofertilizer (1\%).

6- Treatment $2+$ treatment 5

7- Treatment $3+$ treatment 5

8- Treatment $4+$ treatment 5

The closed-dynamic air flow system method (Elbordiny, 2004) was used to determine the daily ammonia loss for 104 days of incubation. The system was consisted of an exchange chamber (pot), $24 \mathrm{~cm}$ height and $26 \mathrm{~cm}$ diameter containing $14 \mathrm{~kg}$ air dried calcareous soil and moistened to $70 \%$ of water holding capacity. Dose of $10 \mathrm{~g} / \mathrm{Kg}$ of urea fertilizer was added on the surface of amended soil samples and thoroughly mixed. Erlenmeyer flask containing $75 \mathrm{ml}$ of boric acid, bromocresol green and methyl red indicator as ammonia trap were used. Both pots and Erlenmeyer flask were stoppered and fitted with an inlet/ outlet. The inlet of the pot was connected to an air pump and the outlet was connected by polyethylene tubing to the ammonia trap. Air was passed through the chambers at a rate of $2.50 \mathrm{~L} / \mathrm{min} /$ pot. This incubation was conducted at room temperature $\left(18^{+} 5^{\circ} \mathrm{C}\right)$ for 104 days. The boric acid indicator traps were replaced every 7 days. The released ammonia was captured in the trapping solution and back-titrated with $0.01 \mathrm{M} \mathrm{HCl}$, until the colour changed from green to purple to measure the ammonia released. The experiment was a completely randomized design with three replicates for each treatment.

\section{RESULTS AND DISCUSSION}

Data illustrated in Table (6) show the amounts of $\mathrm{NH}_{3}$ released under different treatments as calculated per Fadden. In general, ammonia volatilization rates were generally increased by increasing incubation time with the different amendments. The total amount of $\mathrm{NH}_{3}$ lost at the end of the study is shown in Table (6). Soil samples treated with different amendments markedly decreased $\mathrm{NH}_{3}$ loss compared to the untreated soil. The culmination of zeolite, biocher or biocher with bioferti- lizer pronounced reduced $\mathrm{NH}_{3}$ loss as compared to other treatment. Moreover the total $\mathrm{NH}_{3}$ losses out of soil were effectively reduced by treatments of biocher, biocher with biofertilizer or zeolite compared to the total loss from the control. Table (5), indicates that the biofertilizer containing living $\mathrm{mi}-$ croorganisms, which have an ability to make important elements available via biological processes. Therefore, biofertilizer may increase the urea use efficiency and hence decrease nitrogen loss. The present result is in agreement with Ippolito, et al (2011) who reported that the microbial inoculants could be used as an economic input to increase crop productivity with chemical fertilizers. Also, the reduction of ammonia loss for treatment of potassium humate compared with urea alone could be due to the temporary acidic condition at the urea micro site. These results agreed with the work of Ahmed, et al (2009) who found a reduction in ammonia loss when urea was mixed with humic acid. This may have effectively increased the volume of soil treated with humic acid and also increased the time required for complete hydrolysis of urea (Fan and Mackenzie 1993).

The $\mathrm{NH}_{3}$ loss release at the second week of incubation for control treatment, while $\mathrm{NH}_{3}$ loss was at the fifeth weeks with application of potassium humate. The high loss of $\mathrm{NH}_{3}$ for untreated soil was most likely due to the high $\mathrm{pH}$ value of the soil that accelerated the hydrolysis of urea. Since potassium humate was more acidic, the formation of more ammonium over ammonia was possible. A part from having low $\mathrm{pH}$, the total acidity of potassium humate was also high, as urea hydrolysis. A large amounts of ammonium ions may be released into the soil solution due to urea hydrolysess. This positively charged ammonium ions are in turn adsorbed to the negatively charged sites of phenolic and carboxylic groups of potassium humate. As a result, the concentration of ammonia gas in the soil solution which is subject to volatilization was reduced.

On the other hand, application of zeolite, biocher and biofertilizer prolongs the period of $\mathrm{NH}_{3}$ presence to 7 and 8 weeks from incubation. Combination between biofertilizer and potassium humate or zeolite decreased $\mathrm{NH}_{3}$ loss from soil, while biofertilizer mixed with biocher resulted in un formation of $\mathrm{NH}_{3}$. Due to high $\mathrm{pH}$ of the calcareous soil, more microorganisms were able to thrive in the soil and actively breakdown soil organic materials, therefore increasing the total organic carbon in the soil. Increasing ammonia volatilization from untreated calcareous soil may be due to hydro- 
lyzed urea to ammonium carbonate by urease enzyme. Afterwards, ammonium carbonate can decomposes into $\mathrm{NH}_{3}, \mathrm{CO}_{2}$ and $\mathrm{H}_{2} \mathrm{O}$ (Francis, et al 2008). Also, McGarry, et al (1987) found that the ammonia loss is higher under warm - dry and cool - wet conditions which can be overcome by using zeolite. Thus, addition of zeolite to urea fertilizer can improve nitrogen use efficiency as noticed by (McGilloway, et al (2003), Rehakova, et al (2004) and Alberto, et al (2010). Also, Fergunson and peppeer (1987) reported that the main action of zeolite in ammonium conservation is to decrease nitrogen concentration in soil solution through cat ion exchange capacity, high water holding capacity in the free channels, high adsorption capacity and retaining large quantities of ammonium ion in these minerals.

However, the maximum $\mathrm{NH}_{3}$ loss from the control treatment occurred after four weeks of incubation while with potassium humate and zeolite plus biofertilizer occurred at 6 weeks after incubation. In this concern, Hronec, et al (1989) demonstrated that the sorption of ammonium nitrogen on zeolite is extraordinary fast, While in the first minute the sorption of more than $90 \%$ of the maximum potential ammonia concentration on zeolite happened. They added that, during the next period from 2 minutes up to several hours the concentration rate of adsorbed ammonium did not change significantly and it remained almost constant. Therefore, it can be assumed that this process depends on side of the zeolite particles, so increasing the stabilization of sorption equilibrium in time.

Date in Table (7) showed that the maximum lost value from urea is $3.6 \%$ resulted from control treatment, while the lowest value was found by biochar + biofertilizer treatment. The residual values of urea in the studied soil showed an increase by the tested treatments compared to the control with the highest value by biochar + biofertilizer, followed by zeolite, biochar and biofertilizer by rate of 100, 99.99, 99.99 and $99.99 \%$, respectively. These means that the applied treatments increased the available amount of urea to grown plants. On the other hand, application of zeolite, biocher and biofertilizer reduced the amount of urea losses from soil. These results due to zeolite can be used to control $\mathrm{N}$ loss from urea because of the small molecular size of the open-ringed structure of clinoptilolite zeolite which physically protects $\mathrm{NH}_{4}{ }^{+}$ions against microbial nitrification (Ferguson and Pepper, 1987). It was started by biochar improved the biological conditions of soils, increased soil microbial biomass and supported beneficial organisms like earthworms Lehmann et al (2011). That biofertilizers are known to improve fixation of nutrients in the rhizosphere, produce growth stimulants for plants, improve soil stability and provide biological control as mentioned by (Rivera-Cruz, et al (2008).

Table 6. Effect of different treatments on ammonia loss ( $g l f e d)$ from the used Calcareous Soil

\begin{tabular}{|c|c|c|c|c|c|c|c|c|}
\hline \multirow[b]{2}{*}{$\begin{array}{c}\text { Incubation } \\
\text { period } \\
\text { (weeks) }\end{array}$} & \multirow[b]{2}{*}{ Control } & \multicolumn{5}{|c|}{ Soil Treatments } & \multirow[b]{2}{*}{$\begin{array}{l}\text { zeolite } 1 \%+ \\
\text { biofertilizer } \\
\quad+1 \%\end{array}$} & \multirow[b]{2}{*}{$\begin{array}{c}\text { biocher } \\
1 \%+ \\
\text { biofertilizer } \\
+1 \%\end{array}$} \\
\hline & & $\begin{array}{c}\text { Potassium } \\
\text { humate } \\
1 \%\end{array}$ & $\begin{array}{c}\text { zeolite } \\
+1 \%\end{array}$ & $\begin{array}{c}\text { Biocher } \\
+1 \%\end{array}$ & $\begin{array}{l}\text { biofertilizer } \\
\quad+1 \%\end{array}$ & $\begin{array}{c}\text { Potassim } \\
\text { humate } \\
1 \%+ \\
\text { biofertilier } \\
+1 \% \\
\end{array}$ & & \\
\hline 1 & $\mathrm{ND}^{*}$ & ND & ND & ND & ND & N D & ND & ND \\
\hline 2 & 265.0 & ND & ND & ND & ND & N D & ND & ND \\
\hline 3 & 587.2 & ND & ND & ND & ND & 226.4 & 8.7 & ND \\
\hline 4 & 761.4 & ND & ND & ND & ND & 482.5 & 119.4 & ND \\
\hline 5 & 744.6 & 342.0 & ND & ND & ND & 460.7 & 218.0 & ND \\
\hline 6 & 544.8 & 399.1 & 0.7 & 0.7 & ND & 247.9 & 269.1 & ND \\
\hline 7 & 347.4 & 293.7 & ND & ND & 1.4 & 44.4 & 241.1 & ND \\
\hline 8 & 153.9 & 225.6 & ND & ND & ND & ND & 20.3 & ND \\
\hline 9 & 57.8 & 175.8 & ND & ND & ND & ND & ND & ND \\
\hline 10 & 4.3 & 150.8 & ND & ND & ND & ND & 218.7 & ND \\
\hline 11 & ND & 192.0 & ND & ND & ND & ND & 269.1 & ND \\
\hline 12 & ND & 274.4 & ND & ND & ND & ND & 281.7 & ND \\
\hline 13 & N D & 271.5 & ND & 0.7 & ND & N D & 230.1 & ND \\
\hline SUM & 3466.6 & 2325 & 0.7 & 1.4 & 1.4 & 1461.9 & 1876.2 & ND \\
\hline
\end{tabular}


Table 7. Effect of different treatments on ammonia loss and available urea after 13 weeks from calcareous soil

\begin{tabular}{|c|c|c|}
\hline Treatment & $\begin{array}{c}\text { \% of urea } \\
\text { loss }\end{array}$ & $\begin{array}{c}\text { \% of avail. } \\
\text { Urea }\end{array}$ \\
\hline Control & 3.60 & 96.40 \\
Potassium humate & 2.40 & 97.60 \\
Zeolite & 0.0007 & 99.99 \\
Biochare & 0.001 & 99.99 \\
Biofertilizer & 0.001 & 99.99 \\
Potassium humate + & 1.50 & 98.50 \\
biofertilizer & 1.94 & 98.01 \\
Zeolite + biofertilizer & 0.00 & 100 \\
Biochar + biofertilizer & &
\end{tabular}

\section{CONCLUSIONS}

The nitrogen loss due to ammonia volatilization is one of the main factors for low efficiency of urea applied on the surface soil. The reduction of losses by volatilization can be achieved by amending soil using urea mixed with biofertilizer. Moreover, application of biochar and biofertilizer may increase the formation $\mathrm{NH}_{4}$ over $\mathrm{NH}_{3}$ which is retaining more to the soil particles. Reducing ammonia volatilization from urea may also contribute to the reduction of environmental pollution from excessive utilization of nitrogen fertilizers.

\section{REFERENCES}

Abou El-Yazied, A.M. and Sellim. A.S.M. 2007. Effect of Reducing N, P Mineral Fertilization Levels Combined with Bio Fertilizer on Growth, Yield and Tuber Quality of Potato Plants. J. Agric. Sci., 32, 2701- 2726.

Ahmed, O.H., Husni, M.H.A., Anuar, A.R. and Hanafi. M.M. 2009. Reducing ammonia loss from urea and improving soil-exchange ammonium retention through mixing triple superphosphate, humic acid and zeolite. Soil Use Manage., 22, 315 - 319.

Alberto, C.C., Bernardi., A.D., Pereira., E., Mota. B., Siumeire, C., Henrique., C., Cardoso, R.D. and Oliviera, P.P.A. .2010. Ammonia volatilization, dry matter yield and nitrogen levels of Italian ryegrass fertilized with urea and zeolite. Soil Sci., 1, 22 - 25.

Aulakh, M.S. and Malhi. S.S. 2005. Interactions of nitrogen with other nutrients and water: effect on crop yield and quality, nutrient use efficiency, carbon sequestration, and environmental pollution. Adv. Agron. 86, 341 - 409.

Bouzo, L., Lopez., M., Villegas., R., Garcia, E. and Acosta, J.A. 1994. Use of natural zeolites to increase yields in sugarcane crop minimizing environmental pollution. Inter. Soc. Soil Sci. 15, 695- 701.

Brady N.C. and Weil. R.R. 2010. Elements of the Nature and Properties of Soils. $3^{\text {rd }}$. Upper Saddle River, NJ, USA: Pearson Education. 25, 716- 737.

Chirinos, J., Leal, A. and Montilla. J. 2006. Use Alternative Biological Inputs for Sustainable Agriculture in the South of Anzoategui State. Applied and Interdisciplinary Sci., Biotech., Digital Magazine Ceniap Today, 11, 1-7.

Clough, T.J. and Condron. L.M. 2010. Biochar and the nitrogen cycle: Introduction. J. Envir. Qual., 39, 1218- 1223.

Elbordiny, M.M. 2004. Some soil factors affecting air pollution by ammonia volatilization from urea fertilizer. Egypt. J. Soil Sci., 44, 441 451.

Fan, M.X. and Mackenzie. A.F. 1993. Urea and phosphate interactions in fertilizer microsites: Ammonia volatilization and $\mathrm{pH}$ changes. Soil Sci. Soc. Am. J. 57, 839 - 845.

Fergunson, G. and Pepper, I. 1987. Ammonium retention in soils amended with clinoptilolite. Soil Sci. Soc. Am. J., 51, 231- 234.

Francis, D.D., Vigil, M.F. and Moiser, A.R. 2008. Gaseous losses of nitrogen other than through denitrification. In: Nitrogen in Agricultural Systems, pp: 255 - 262, A.S. of Agronomy, C.S.S. of America and S.S.S. of America, (eds.). Agron. Monograph 49. Madison, Wisc., USA.

Glaser, B., Lehmann, J. and Zech, W. 2002. Ameliorating physical and chemical properties of highly weathered soils in the tropics with charcoal- A review. Biol. and Fert. of Soils 35, 219-230.

He, Z.L., Calvert, D.V. and Alva, A.K. 2002. Clinoptilolite zeolite and cellulose amendments to reduce ammonia volatilization in a calcareous sandy soil. Plant Soil 247, 253 - 260. 
Hronec, O., Sidor, E. and Dzunko, J. 1989. Speed of cat- ions sorption on the zeolite rock and on its mixture with soil. Polnohospodarstvo 35, 108 - 113.

Ippolito, J.A., Tarkalson, D.D. and Lehrsch, G.A. 2011. Zeolite soil application method affects inorganic nitrogen, moisture and corn growth. Soil Sci, 176. 136 -142.

Jackson, M.L. 1958. "Soil Chemical Analysis". Prentic-Hall, Inc. Englewood Cliffs, N.J. Library of Congress, USA. pp. 115-230.

Kamarudin K.S., Hamdan, H. and Mat, H. 2003. Methane adsorption characteristic dependency on zeolite structures and properties. Proc Symp. Malaysian Chem. Engineers; Penang, Malaysia. 3, 111-120.

Lehmann, J., Rillig, M.C., Thies., J., Masiello., C.A., Hockaday, W.C. and Crowle, D. 2011. Biochar effects on soil biota- A review. Soil Biology and Biochem., 43, 1812 - 1836.

McGarry, C.T., Tucker, T.C. and Dzunko. J. 1987. Ammonium nitrogen movement in a course-textured soil amended with zeolite. Soil Science Society of America Journal. 1, 235238.

McGilloway, R., Weaver., R., Ming, D. and Gruener. J.E. 2003. Nitrification in a zeoponic substrate. Plant Soil 256, 371 - 378.

McHenry, M.P. 2011. Soil organic carbon, biochar, and applicable research results for increasing farm productivity under Australian agricultural conditions. Commun. Soil Sci. and Plant Analysis 42, 1187- 1199.

Miles, D.M., Rowe, D.E. and Cathcart. T.C. 2011. High litter moisture content suppresses litter ammonia volatilization. Poult. Sci., 90, 13971405.

Paramasivam S., Alva., A.K., Fares, A. and Sajwan, K.S. 2001. Estimation of nitrate leaching in an Entisol under optimum citrus production. Soil Sci. Soc. Ame. J., 3, 914 921.
Powlson D.S., Addiscott, T.M. and Benjamin. N. 2008. When does nitrate become a risk for humans? J. Environ. Qual., 2, 291 - 295.

Rabai, K.A., Ahmed, O.H. and Kasim, S. 2013. Use of formulated nitrogen, phosphorus, and potassium compound fertilizer using clinoptilolite zeolite in maize (Zea mays L.) cultivation. Emirates J. Food and Agri., 9, 713-722.

Rehakova, M., Cuvanova., S., Dzivak., M., Rimár, J. and Gaval'ovác, Z. 2004. Agricultural and agrochemical uses of natural zeolite of the clinoptilolite type. Current Opinion in Solid State \& Materials Science 8, 397 - 404.

Rivera-Cruz, M., Trujill., A., Córdova., G., Kohler., J., Caravaca, F. and Roldán, A. 2008. Poultry Manure and Banana Waste Are Effective Bio-Fertilizer Carriers for Promoting Plant Growth and Soil Sustainability in Banana Crops. Soil Biol. Bioch., 40, 3092 - 3095.

Sharma, S.D. and Kumar, P. 2008. Relationship of Arbuscular Mycorrhizal Fungi and Azotobacter with Plant Growth, Fruit Yield, Soil and Leaf Nutrient Status of Mango Orchards in Northwestern Himalayan Region of India. J. Environ. Qual., 4: 291 - 295.

Spokas, K.A., Novak, J.M. and Venterea. R.T. 2012. Biochar's role as an alternative $\mathrm{N}$ fertilizer: ammonia cap. Plant and Soil 350, 35 $-42$.

Steiner, C., Das., K.C., Melear, N. and Lakly, D. 2010. Reducing nitrogen loss during poultry litter composting using biochar. J. Environ. Qual., 39, 1236 - 1242.

Vitosh M.L., Johnson, J.W. and Mengel. D.B. 1995. Tri-state fertilizer recommendation for corn, soybeans, wheat, and alfafa. Exten. Bull., 4, 25-67.

Wolf, B. and Snyder. G.H. 2003. Sustainable Soils: The Place of Organic Matter in Sustaining Soils and Their Productivity. New York, NY, USA: Food Products Press., 30, 112 - 119. 